\title{
Historia en tiempo real de las bacterias del siglo XXI: gigantes y marcianas
}

\author{
Walter Ledermann ${ }^{1}$
}

${ }^{1}$ Centro de Estudios Humanistas Julio Prado.

Recibido: 16 de enero de 2019

Correspondencia a: Walter Ledermann $\mathrm{D}$. oncemayor@gmail.com

Real time history of 21 st century bacteria: giants and martians.

We denominate " 21 st century bacteria" two types of strange and amazing creatures from the kingdom Protista, discovered between the last years of the twentieth and the present days: the giant bacteria and those with a possible Martian origin. Searching for them, bold investigators have travelled to distant and hostile lands, desolate places and deep waters, performing a kind of investigation that we only can describe as "investigation-adventure". This paper presents expeditions to the Red Sea, fishing the Epulopiscium; to Lake Mono, searching a bacteria able to growth with arsenic; to the Antarctic Circle, finding a meteorite with petrified alien microorganisms; and... to the quiet laboratory, a not less dangerous place.

Key words: Giant bacteria; mars bacteria; adventure investigation.

Palabras clave: Bacteria gigante; bacteria marciana; investigación aventura.

\section{El tiempo real}

$\mathrm{E}$ 1 tiempo fluye -o parece fluir- en una sola dirección $\mathrm{y}$, de acuerdo a nuestra experiencia, siempre lo hace hacia delante, aunque las leyes de la física formuladas desde Newton hasta hoy, pasando por Maxwell y Einstein, muestran una completa simetría entre pasado y futuro, estando el primero ligado a lo sucedido realmente y el segundo moldeable y abierto a todas nuestras posibilidades y esperanzas; y entre ambos el ahora, un punto de soporte temporal, que se reinventa a cada momento ${ }^{1}$. Permítanos decirle, estimado lector, que segundo a segundo se está haciendo historia y éste es ya un artículo añejo, sobre hechos antiguos; aunque éstos le parezcan recientes, ya son historia, así como lo que encuentra hoy en el diario matutino es el ayer, el pasado, irrevocable e irreversible para nosotros (pero no para la física teórica).

No podemos detener el tiempo, de modo que intentaremos correr con él, haciendo "en tiempo real", como dicen de la reacción de polimerasa en cadena, un relato simplificado de las bacterias del siglo XXI. Sorprenderá a nuestros lectores el tenor de este ensayo, pero estamos ciertos que tras alguna reflexión, aceptarán que la historia no tiene, necesariamente, que ser "antigua", herrumbrosa y hasta putrefacta; que es cosa viva, desarrollándose minuto a minuto ante nuestros ojos, y que somos, hablando en lenguaje de cine, poquísimas las estrellas y menos los actores principales, muy escasos los de reparto, y los extras o los simples espectadores la inmensa mayoría.

\section{Investigación-aventura buscando bacterias del siglo XXI}

Así como existe un "turismo-aventura", donde en lugar de descansar el viajero se dedica a actividades deportivas que amenazan con romperle el alma, existe una investigación científica donde los sabios toman muestras en ríos, desiertos y nieves eternas, en busca de respuestas a los enigmas de la biología, a la cual podríamos llamar "investigación aventura". En esta ocasión, mostraremos algunos ejemplos de esta actividad en relación a dos tipos de bacterias, cuya investigación se iniciara a fines del siglo $\mathrm{XX}$, para estallar con singular brillo en el actual, que son las bacterias gigantes y las bacterias de Marte.

\section{El pez cirujano del Mar Rojo}

Mientras una bacteria patógena mide entre 1 y 2 micrones, alcanzando algunas saprófitas hasta 7 micrones, las llamadas con toda justicia gigantes pueden ser visibles a simple vista. Estas maravillas son de dos clases: las que albergan miles de copias de su genoma en la periferia de su enorme masa citoplasmática y las que están tan sólo "hinchadas" por una tremenda vacuola central. Unas y otras son marinas.

El pez cirujano marrón descrito con el tremendo nombre de Acanthurus nigrofuscus no ejerce la cirugía: su nombre le viene de dos espinas presentes en su pedúnculo caudal, que emplea como aguzados bisturíes para defenderse e imponerse a sus competidores. Es aplastado lateralmente, casi plano, de forma ovalada; mide entre $5 \mathrm{y}$ 
$21 \mathrm{~cm}$, tiene un tremendo hocico y entre 22 y 30 dientes, según el tamaño del ejemplar. Este curioso bicho marino puede vivir hasta 16 años, "pastoreando" (así dicen los expertos) entre las algas filamentosas que constituyen su alimento.

Es fácil mantener a estos cirujanos en cautiverio, pues no agreden a otras especies, aunque pelean con otros de su mismo género. Necesitan, eso sí, de un acuario grande, con harta luz para que crezcan algunas algas y con hartas rocas sintéticas para esconderse. Como son delicados de piel hay que usar esterilizadores de luz ultravioleta para eliminar posibles plagas.

En 1985, en el intestino de uno de estos peces que nadaba en el Mar Rojo, se encontró viviendo como simbionte a un extraño microorganismo. Este simbionte fue denominado Epulopiscium fishelsoni (en adelante "el epulo") y se estimó por su tamaño, que puede alcanzar 300 a 600 micrones, que no era un protista, sino un ser del reino Protoctista ${ }^{2}$. Más tarde se vio que no tenía organelos propios de los eucariotes, que carecía de membrana nuclear, que su pared celular, su citoplasma y sus flagelos eran bacterianos, reubicándolo en el reino Protista, pasando a ser la bacteria más grande conocida, visible incluso a simple vista, sin necesidad de microscopio (Figura 1).

Fundamentales para clasificarla como tal fueron los estudios de Esther Angert en 1993, quien ya había demostrado que esta bacteria contenía una tremenda concentración de ADN cerca de su membrana celular, para concluir, tras análisis de material genético, que era una bacteria Gram positiva relacionada al género Clostridium $^{3}$.

\section{Corriendo del mar al laboratorio}

Corroborando su hallazgo y describiendo su complejo ciclo de vida diario está la investigación-aventura de Bresler y cols., desarrollada en el Mar Rojo y en laboratorios en Eilat y Tel Aviv, publicada en $1998^{4}$. No siendo la bacteria cultivable, los investigadores debían obtenerla a diario pescando en el Great Barrier Reef del Mar Rojo. Como de noche el pez está inactivo y dormido en el fondo del mar, preciso era capturarlo de día, cuando está en la superficie, usando una red o con arpón.

Así pues, los intrépidos investigadores pescaban de día y luego llevaban a matacaballo sus pescados al laboratorio, donde les daban un martillazo en la cabeza y los disecaban de inmediato, observando los epulos del intestino dentro de los próximos $15 \mathrm{~min}$, con fluorometría, microscopia electrónica y otros sofisticados métodos. Como Tel Aviv estaba muy lejos, las muestras se trabajaron inicialmente en el Instituto Interuniversitario de Eilat, ciudad costera del golfo de Aqaba. Para muestras nocturnas, los peces capturados al atardecer se conservaban en estanques y se mataban de noche, cuando dormían.

Durante el día, los epulos crecían hasta 20 veces de largo, de 30 a 600 micrones, y entre 2.000 y 3.000 veces en volumen. Bresler y cols. demostraron que tienen un complejo ciclo de vida, tanto que no se reproducen por simple división, naciendo dos células al interior de la madre a partir de unos nucléolos de ADN, que luego se rodean de citoplasma hasta llenar la célula madre, pinchando ADN cerca de la mitad de la célula, para rodearse finalmente de pared celular, reventar la célula madre y salir al mundo. Estos nucleolos tienen muchas copias del genoma, más las que pinchan antes de nacer.

\section{Poder femenino: Jennifer Mendell y Esther Angert investigan}

Diez años después, en el 2008, encontramos otra investigación capital, la de Jennifer Mendell, de la Universidad de Cornell, demostrando su "extrema poliploidía". Mendell estudió la frecuencia de tres genes, encontrando que los epulos más grandes tenían hasta 41.000 copias de cada uno, mientras Buchnera aphidicola, que vive dentro de áfidos y era hasta entonces la campeona, tenía apenas 120 copias.

Esther Angert, de la Universidad de Cornell, en Ithaca, New York, afirmaría más tarde que las copias pueden llegar a 200.000. Con femenino sentimiento, la definió como "una bacteria muy hermosa y elegante", e inició su estudio criando peces unicornio en el laboratorio para reproducir los epulos en su intestino, evitándose la molestia de salir a pescar.

Esta estrategia de tener más de dos copias, como los imprevisores humanos, se llama poliploidía. Las implicaciones de este fenómeno son múltiples y ventajosas, como la posibilidad de sobrevivir a mutaciones deletéreas, en tanto que su mayor tamaño le facilita su alimentación

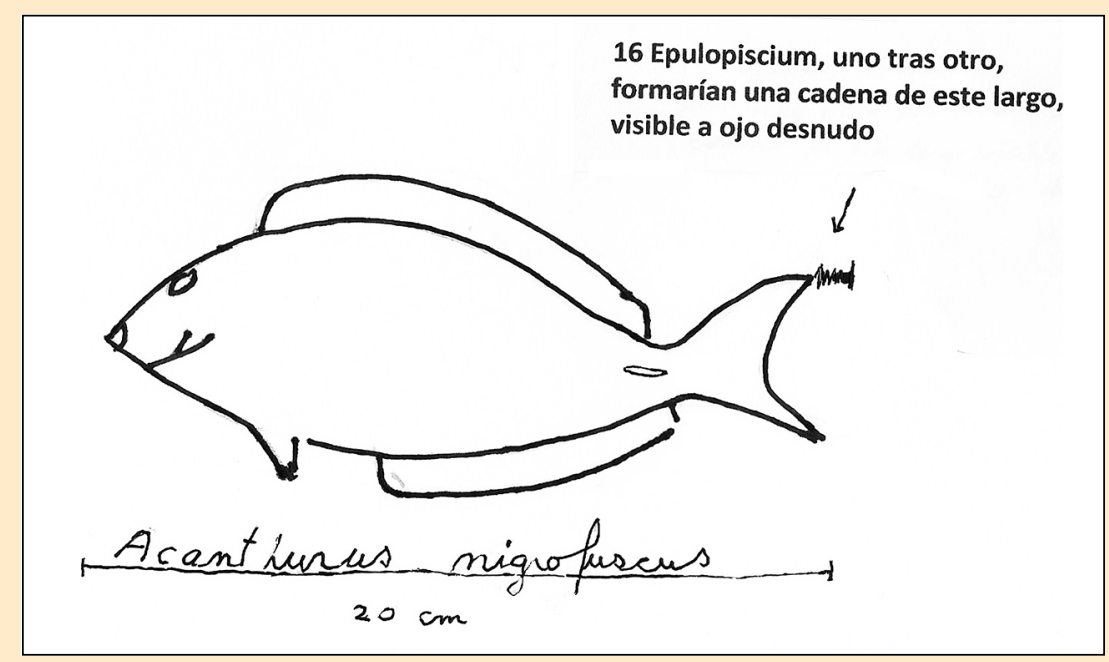

Figura 1. 
al interior del pez; como vemos, este genoma múltiple le permite hacer muchas cosas a la vez... Esther Angert afirma que estando los genes debajo de la pared celular, al encontrar nutrientes se activan de inmediato las enzimas necesarias para metabolizarlos.

Otros diez morfotipos del epulos se han encontrado en peces cirujanos en los mares de Hawaii, Polinesia francesa, Guam, Tuvalu, Nueva Guinea, Japón y Sudáfrica ${ }^{6}$.

Si era entre las bacterias Epulopiscium la más grande del mundo, poco le duró su record, que le fue arrebatado al fin del siglo XX por la Thiomargarita namibiensis, con un tamaño de 750 micrones, es decir, tres cuartas partes de un milímetro, lo cual la hace visible a simple vista.

\section{La perla sulfúrica de Namibia}

Thiomargarita pertenece al segundo grupo de bacterias gigantes, aquellas que lo son por tener una enorme vacuola central, llegando a ocupar $98 \%$ de su volumen. Fue descubierta en 1997, en muestras tomadas del fondo marino frente a las costas de Namibia por el navío ruso Pyotr Kottsov en el curso de una expedición oceanográfica que lideraba la intrépida investigadora alemana Heidi Schulz, acompañada de Timothy Ferdelman, Bo Barker Jorgensen, del Instituto Max Planck; de Thorsten Brinkhoff, de la Universidad de Oldenburg; Mariona Hernández Mariné, de la Universidad de Barcelona; y Andreas Teske, de la Woods Hole Ocenographic Institution de EE. UU.

Este navío, construido para la investigación en 1991, tiene 65 metros de largo y un peso de 1.698 toneladas. No es la gran cosa, pero como buena máquina rusa, es resistente a toda prueba y ha sido utilizado en varias expediciones científicas.

Al analizar las muestras extraídas de la profundidad marina, los investigadores encontraron en ellas una sulfurbacteria gigantesca nutriéndose de sulfuros y nitratos, a la cual llamaron Thiomargarita namibiensis, de thio, azufre, y Margarita, quizás porque los germanos siempre han sido incurables románticos, lectores de Goethe y a lo mejor éstos también de Rubén Darío; y namibiensis, por Namibia ${ }^{7}$.

A simple vista se ve blanducha, por los gránulos de sulfuro en la vacuola, que brillan un poquito con la luz. Como estas bacterias se mantienen unidas formando largos filamentos, gracias a un mucílago que recuerda algunos biofilm, algunos investigadores hablan de un tamaño "de varios centímetros". En la vacuola central se almacenan los nitratos, concentrados 10.000 veces en relación a su entorno, con los cuales la margarita oxida los sulfuros, que le son vitales. La "Perla sulfúrica de Namibia", como se la ha llamado por su disposición en cadenas como un collar de perlas, se ha adaptado a un medio pobre en oxígeno y alto en sulfuro de hidrógeno,

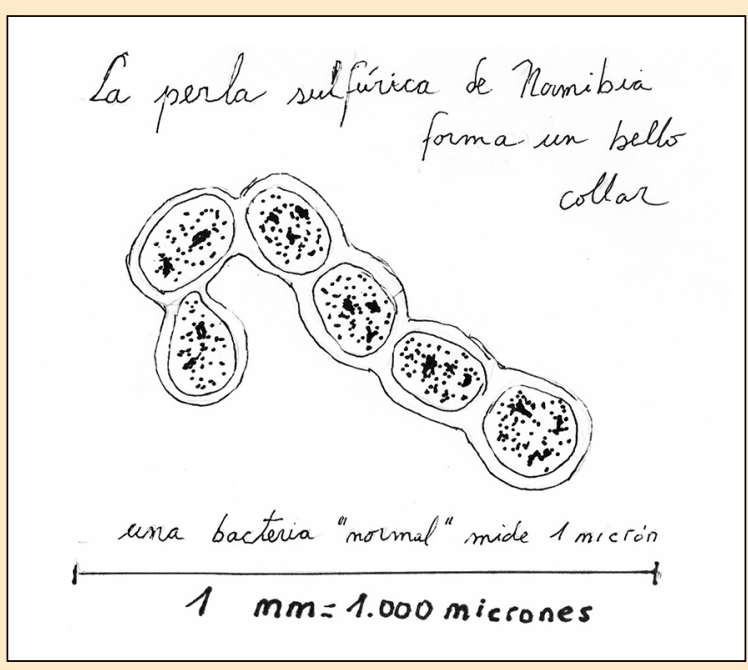

Figura 2.

que sería tóxico para la mayor parte de los seres vivos (Figura 2).

Cuando comenté este hecho con mis colaboradores, al principio no me creían porque la bacteria era demasiado grande-dijo Heidi Schulz-, entonces estudiante de doctorado del Instituto Max Planck.

\section{Buscando la Thioploca y la Beggiatoa}

El azar colabora con la investigación, pues la expedición del Pyotr a las costas de Namibia iba en busca de otras dos bacterias del azufre-Beggiatoa y Thioplocaya estudiadas en las costas sudamericanas del Pacífico, similares a las de Namibia, pues existen en unas y otras fuertes corrientes oceánicas, que se desplazan dirección norte-sur.

Las bacterias del género Thioploca, que también se alimentan de nitratos, formando grandes poblaciones en los sedimentos de las costas occidentales de América del Sur, fueron descubiertas con anterioridad, pero en tamaño son diez veces menores que la Thiomargarita. Estas bacterias se disponen formando filamentos multicelulares verticalmente sobre los sedimentos. En tales estructuras filamentosas, en la parte superior se extraen los nitratos del agua y en la inferior el sulfuro de hidrógeno del sedimento, que luego se guarda en la vacuola como azufre. Para esta tarea se mueven en forma rítmica, bajando al sedimento y luego subiendo con su trofeo. Thiomargarita, aun cuando pariente de Thioploca, ni tiene ni necesita este movimiento, pues con la gran cantidad de nitratos que guarda en su vacuola y con el azufre en forma de glóbulos que tiene en su periferia, puede sobrevivir por dos o tres meses sin otros nutrientes: como el ganso Glad Consuerte imaginado por Walt Disney, nuestra Margarita 
espera que una tormenta sacuda las aguas, removiendo los sedimentos, y le lleguen los nitratos del fondo, pues todo le llega al que se sienta y espera. Por otro lado, es muy resistente a altas concentraciones de oxígeno o sulfuro, que matarían a la Thioploca.

El género Thioploca fue descrito y nominado por Lauterborn en 1907, quien de paso describió su especietipo, la Thioploca schmidlei. Derivó su nombre de los vocablos griegos theion, latinizado como thium, que significa sulfuro; y plokê, trenza ${ }^{8}$. S. Maier y V.A. Gallardo describieron en 1984 dos especies chilenas: Thioploca araucae sp. nov. y Thioploca chileae sp. nov. ${ }^{9}$. Estas bacterias tienen una vacuola llena de sulfuro y nitrato, que ocupa más de $80 \%$ de su célula, y se dispone al interior de largos filamentos formados por miles de bacterias, de donde sale la confusión de decir que mide varios centímetros, entre 5 y 10. En América del Sur se la encuentra a lo largo de 3.000 kilómetros de la costa oeste: de ahí que Gallardo haya tenido ocasión de estudiarla. Secreta una vaina de mucus, que usa como un túnel que conecta el sulfuro del fondo del mar con el nitrato del agua del mar ${ }^{10,11}$.

\section{Fantástica historia de las bacterias de Marte}

Ya en la Antigua Grecia, Anaxágoras elaboró la teoría de la panspermia, según la cual la semilla de la vida se habría repartido por todo el universo ${ }^{12}$. En 1976, durante una célebre conferencia, Francis Crack, el de la doble hélice, dijo que la vida pudo haber llegado a la Tierra desde el espacio, traída por una espora bacteriana muy resistente, como Bacillus subtilis. La secuenciación completa de esta bacteria hizo pensar que allí estaría escrito un mensaje divino, un código de vida, pero nada se encontró, tras una década de estudios, salvo constatar que la mayor parte de los genes tenían funciones desconocidas ${ }^{13}$.

\section{Las expediciones Viking y el proyecto Moon-Mars}

Inspirada quizás en estas ideas la NASA ha buscado en forma pertinaz bacterias en Marte, empezando con el programa Mariner 9 en 1971, que consistió en el exitoso lanzamiento de una sonda orbital al planeta rojo. Esta sonda permitió echar una miradita desde la altura y elegir los mejores lugares para un descenso que luego harían en 1975 las dos naves del Programa Viking. Los norteamericanos hicieron una inversión colosal para esos años, de mil millones de dólares, que hoy son un moco de pavo, lanzando la Viking I en agosto y la Viking II en septiembre, ambas en sendos cohetes Titán III-E, todos estos nombres de evocación épica. Una parte importante de la información que se esperaba obtener es biológica: derechamente, querían ver si existía vida, para lo cual llevaban un increíble y sofisticado equipo.

Este equipo, el Biology Instrument, estaba destinado a realizar tres experimentos, siendo el primero la asimilación de carbono 14 mediante fotosíntesis por muestras tomadas del suelo marciano, expuestas a luz ultravioleta en una atmósfera con este elemento marcado. El segundo consistía en ver si en las muestras de suelo marciano había seres vivos, o algo parecido, capaces de asimilar moléculas orgánicas como aminoácidos: la existencia de estos hipotéticos seres, bacterias u otras entidades microscópicas, se demostraría con la liberación de algunos gases conteniendo el carbono marcado de los aminoácidos. Y el tercero, más sofisticado, buscaba un intercambio entre estas posibles bacterias y la atmósfera marciana, a ver si las bacterias hipotéticas asimilaban algo y expelían anhídrido carbónico, metano o nitrógeno.

En el primer experimento las bacterias, invisibles e imaginarias, soltaron de inmediato algunos gases, que se estimaron de $\mathrm{CO}_{2}$; en el segundo nada ocurrió; en el tercero, tras 200 días de observación, les pareció que variaba el nitrógeno y aumentaban el oxígeno y el $\mathrm{CO}_{2}$.

Después del primer entusiasmo, los científicos de EE. UU. recapacitaron en que los resultados del primer experimento, por su inmediatez, no podían atribuirse a bacterias, sino a procesos químicos o geológicos, una respuesta de la materia inorgánica marciana, la misma que habría respondido, aunque más lentamente, en el experimento tres. Quizás, se dijeron, si los Viking hubieran cavado un poquito más...

Para remate, en los años siguientes, las críticas a los investigadores marcianos que estudiaron las muestras fueron despiadadas, por no haber obtenido buenas muestras ni saber interpretar los resultados, y porque con tantas manipulaciones en tres experimentos, quizás habían terminado por matar a las bacterias marcianas, que no estaban acostumbradas al maltrato que a diario sufren las terrestres ${ }^{14,15}$.

Tras estas críticas, se planearon a largo plazo y concienzudamente las próximas investigaciones $y$, buscando un ambiente similar a Marte, eligieron el desierto de Atacama para una serie de investigaciones sobre la vida bacteriana en terrenos adversos, en las que han colaborado estrechamente microbiólogos de la Universidad de Antofagasta, para culminar con el anuncio del Programa Moon-Mars. Para este proyecto, Chile destinaría a la Universidad de Antofagasta, por cinco años y a través de Bienes Nacionales, un terreno de 153 hectáreas, cerca de la antigua estación ferroviaria Yungay, $80 \mathrm{~km}$ al sureste de esa ciudad. Este proyecto, además de la astrobiología, como se llama al estudio de las bacterias del espacio, estudiaría robótica. Siempre que algún día funcione, pues las trabas burocráticas han sido muchas. 


\section{El color que cayó del cielo}

En 1927 Howard Philips Lovecraft publicó "El color que cayó del cielo", color traído desde el espacio exterior por un meteorito y del todo ajeno al espectro visible por el ojo humano. El alien así transportado se habría escondido adentro de un pozo, convirtiendo los campos vecinos en un "erial maldito", a medida que su color se va extendiendo y destruyendo o deformando todo a su paso, vegetales, animales y hombres, quienes terminan por enloquecer y morir ${ }^{16}$.

Recordamos esta historia cuando en 1984 fue encontrado en la zona norteamericana de la Antártica un meteorito que se bautizó como Allen Hills, determinándose en 1993 que su origen era marciano. Su edad se ha estimado en 4.000 millones de años $\mathrm{y}$, habiendo sido expulsado al espacio tras el impacto de un cometa en Marte hace 16 millones de años, llegó a la Tierra hace apenas 13.000. Es uno de los doce -otros dicen 57- meteoritos hasta ahora identificados como marciano y pesa $1.931 \mathrm{~g}$. Es de Marte porque tiene el isótopo 15 de nitrógeno, hasta ahora sólo hallado en la atmósfera de ese planeta en todo el sistema solar ${ }^{17}$.

A partir de este hallazgo, la obsesión de la NASA la llevó a precipitarse. Primero, en el marzo de 1996 anunciaron oficialmente que en este meteorito, denominado ahora ALH 84001, "había restos de vida orgánica, que según el investigador, Richard Hoover, podrían corresponder a bacterias". Se veían como gusanillos petrificados, de un tamaño inferior al de las bacterias terrestres. Al comunicarlo al presidente Clinton, éste dejó todo lo que tenía entre manos en ese momento, no podemos imaginar qué, y corrió a hacer el histórico anuncio, el 7 de agosto de 1996: "Este es el producto de años de exploración y meses de estudios intensivos por parte de algunos científicos más prestigiosos del mundo. Como todos los descubrimientos, éste deberá ser revisado, examinado y sometido a escrutinio. Debe ser confirmado por otros cientificos...Estoy determinado a que el programa espacial americano ponga todo su poder intelectual y tecnológico tras la búsqueda de más evidencia de vida en Marte"18.

Después vino la dolorosa retractación, reconociendo que las imágenes correspondían a probable contaminación terrestre. Y luego, un sorprendente anuncio: los cristales de magnetita $\left(\mathrm{Fe}_{3} \mathrm{O}_{4}\right)$, presentes en dicha piedra, en la Tierra son empleados en electrónica y se obtienen de bacterias del género Magnetospirillum. Estas bacterias son las únicas capaces de producir en toda su pureza tales cristales, armándolos laboriosamente molécula a molécula, para poder alinearlos en el sentido magnético de nuestro planeta ${ }^{19}$. Esta vez no puede pensarse en contaminación, pues los cristales están profundamente incrustados, tienen la edad geológica del meteorito y en la zona donde aterrizó el Allan Hills no hay bacterias capaces de fabricar magnetita. ¿Entonces... son bacterias marcianas las que los pusieron en el meteorito?

\section{El enigma del lago Mono}

El lago Mono se halla situado en medio de un desierto sin vida, sin árboles, horrendo, a 8 mil pies de altura sobre el nivel del mar, y está guardado por montes de dos mil pies todavía más altos, cuyas cimas están siempre envueltas en nubes. Este mar solemne, silencioso, no surcado por embarcaciones - este solitario ocupante del lugar más solitario de la tierra-se halla muy poco favorecido por paisajes pintorescos. Es una gran extensión sin pretensiones, de agua gris, de un centenar de millas de circunferencia, con dos islas en su centro, que son unos montones de lava desgarrada, pelada y abrasada; con nevados de grises bancos y de barrancos de piedra pómez y de cenizas, mortaja de muerto volcán de cuyo inmenso cráter se ha apoderado el lago, ocupándolo.

Tiene doscientos pies de profundidad y sus aguas dormidas son tan fuertemente alcalinas, que basta con meter en ella una o dos veces la prenda de ropa más sucia y retorcerla, para que salga tan limpia como si hubiera pasado por las manos de la más hábil lavandera. Un perro, que tenía en el cuerpo más mataduras que pedazos sanos... saltó por la borda de la lancha... el agua alcalina le mordió en todos los lugares simultáneamente y el animal se lanzó hacia la orilla con vivisimo interés... iba ladrando, aullando y bramando... cuando llegó a la orilla corrió, trazando círculos y círculos, arañó el suelo y despedazó el aire, unas veces hacia atrás y otras adelante, de la manera más extraordinaria ... se lanzó a las montañas a doscientas cincuenta millas por hora y aun sigue corriendo... esto ocurrió hace nueve años y todavía buscamos lo que haya podido quedar de él en este mundo.

Esta vívida descripción pertenece a Mark Twain, quien anduvo por allí en su juventud "pasando fatigas" ${ }^{20}$.

\section{Científicos acampan junto al lago Mono}

En el año 2010 una expedición de la NASA, encabezada por Felisa Wolfe Simon viajó al lago Mono a buscar la presencia de bacterias de la familia Halomonadacea, que fueran capaces de usar arseniato en su metabolismo. Fotos en internet muestran a la investigadora, con un sombrerito de lo más mono (como el lago), metida en el agua hasta las rodillas, pero sin botas, quizás porque no conocía la historia del perro o porque Twain exageró y el agua no es tan alcalina, tomando muestras con ayuda de su ayudante Roland Omerland. De éstas se obtuvo una misteriosa bacteria, bautizada provisoriamente como 
GFAJ-1 (Give Felisa A Job), que tenía la particularidad única y nunca vista de reemplazar en algunas moléculas el fósforo por arsénico. Nitrógeno, oxígeno, hidrógeno y fósforo conforman el ADN, pero nunca, nunca podría imaginarse el tóxico arsénico metido allí. Obviamente, dicha bacteria no era de este mundo, o bien, con ella se abría la posibilidad de distintas formas de vida en la Tierra. Su artículo controversial, narrando los resultados de su aventura en el lago Mono, apareció en junio de 2011 en Science, tras haber estado "en línea" durante seis meses de espera ${ }^{21}$ (Figura 3).

\section{Ladrando en las redes sociales}

Este increíble hallazgo motivó un general rechazo, que se expresó, curiosamente, a través de esas entidades viperinas denominadas "redes sociales". En twitter y facebook colegas despechados dijeron que el trabajo estaba mal hecho y que el arsénico encontrado era una contaminación de laboratorio, pues sabido es que al usar métodos como la reacción de polimerasa en cadena una molécula contaminante se multiplica por millones, que no en vano su inventor dijo que, siendo difícil encontrar una aguja en una pajar, era fácil encontrar un millón de ellas.

Luego de las críticas recibidas por esta publicación el sitio web Retraction Watch de Science dijo que los autores debían retractarse por una presentación errónea de la información crítica, pero hasta octubre de 2014 no se había anunciado tal retractación.

Por su parte, la NASA respondió, con toda razón, que los trabajos científicos debían ser discutidos o refutados, si ese era el caso, mediante publicaciones en revistas acreditadas, opinión que corroboró la investigadora. Aunque ya no pertenece a la institución, Felisa Wolfe Simon ha seguido trabajando y publicó sus descargos en Science, pero el daño ya estaba hecho, la desconfianza era general y la bacteria GAFJ-1 fue descalificada y olvidada. Siguiendo la rigurosa ley de la investigación científica, los resultados deben ser reproducibles... y éstos no lo fueron. En el año 2012 dos publicaciones aparecieron en la misma revista Science refutando los aspectos más significativos del trabajo. En el mismo año, otros investigadores de la University of British Columbia y de la Princeton University, publicaron sendos estudios buscando la presencia de arsénico en el ADN de la bacteria GFAJ-1, empleando diferentes técnicas, y no hallaron ni trazas de este elemento. Peor aún, descubrieron que la bacteria no crecía en presencia de arseniato, demostrando que el arsénico le era ajeno y que mal podía participar en sus procesos biológicos ${ }^{22,23}$.

¿Qué habría dicho Mark Twain?

Mark Twain hubiera sonreído, meneando la cabeza

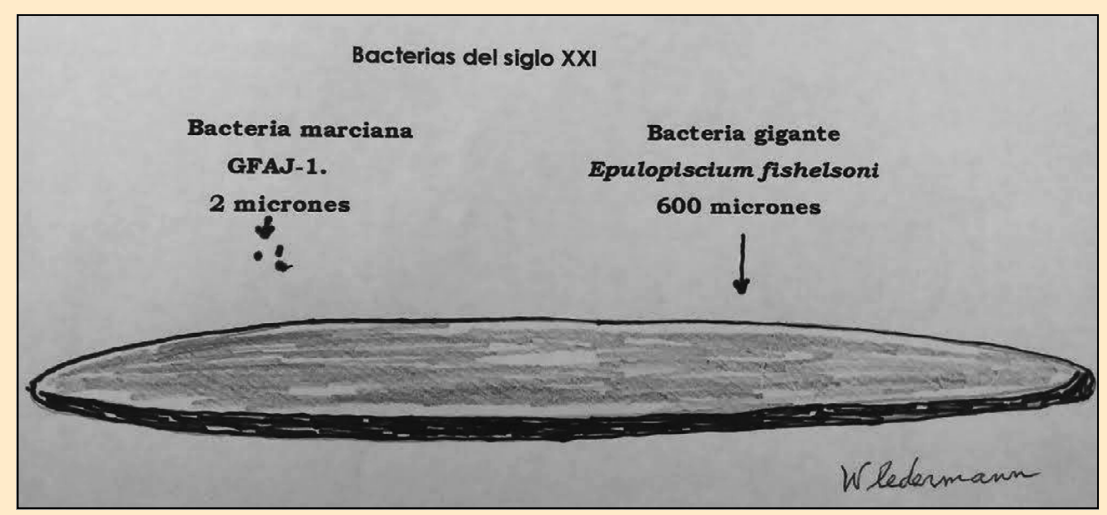

Figura 3.

y diciendo:

- Si en nueve años no encontramos al perro, menos podríamos hallar una bacteria de Marte.

\section{Resumen}

Hemos denominado bacterias del siglo XXI a dos tipos de extrañas y maravillosas criaturas del Reino Protista, descubiertas entre los últimos años del siglo pasado y los días que hoy vivimos: las bacterias gigantes y las de un posible origen marciano. En su búsqueda, audaces investigadores han viajado a tierras distantes y peligrosas, acampando en lugares desolados y descendiendo a las profundidades marinas, actividades que llamamos investigación aventura. Presentamos como ejemplos una expedición al Mar Rojo, buscando el gigantesco Epulopiscium; una temporada en el lago Mono, California, en pos de una bacteria con arsénico en su ADN; un patrullaje en el Ártico, para encontrar bacterias petrificadas en un meteorito marciano; sin olvidar que el tranquilo laboratorio también puede ser un lugar peligroso, porque toda investigación es una aventura.

\section{Referencias bibliográficas}

1.- Greene B. El tejido del cosmos. Espacio, tiempo y textura de la realidad. Dakontos Bolsillo, Crítica, Barcelona 2010; pp. 169-230.

2.- Fishelson L, Montogomery W L, Myrberg A A. A unique symbiosis in the gut of tropical herbivorous surgeonfish (Acanthuridae: Teleostei) from the Red Sea. Science 1985; 239: 49-51.

3.- Angert E R, Clements K D, Pace N R. The largest bacterium. Nature 1993; 362: 239-41.

4.- Bresler V, Montgomery W L, Fishelson L, Pollak E. Gigantism in a Bacterium, Epulopiscium fishelsoni, Correlates with Complex Patterns in Arrangement, Quantity, and Segregation of DNA. J Bacteriol 1998; 180 (21): 5601-11. 
5.- Mendell J E, Clements K D, Choat J H, Angert E R. Extreme polyploidy in a large bacterium. Proc Natl Acad Sci USA 2008; 105:6730-6307. DOI: 10.1073/pnas.0707522105.

6.- Clements K D, Bullivant S. An unusual symbiont from the gut of surgeonfishes may be the largest know prokaryote. J Bacteriol 1991; 173: 5359-62.

7.- $\quad$ Schulz H N, Brinkhoff T, Ferdelman T G, Hernandez Mariné M, Teske A, Jorgensen B B. Dense populations of a Giant Sulfur Bacterium in Namibian Shelf Sediments. Science 1999; 284: 493-5.

8.- Euzéby P. List of Prokariotic names with Standing in Nomenclature-Genus Thioploca. See: Skerman VBD, McGowan V and Sneath PHA (editors): Approved Lists of Bacterial Names. Int J Syst Bacteriol 1980; 30: 225-420.

9.- Maier S, Gallardo V A. Thioploca araucae sp. nov. and Thioploca chileae sp. nov. Int J Syst Bacteriol 1984; 34: 414-8.

10.- Fossing H, Gallardo V A, Jørgensen B B, Hüttel M, Nielsen L P, Schulz H, et al. Concentration and transport of nitrate by the mat-forming sulphur bacterium Thioploca. Nature 2002; 374 (6524): 713-5. DOI: 10.1038/374713a0.

11.- Teske A, Ramsing N B, Küver J, Fossing H. Phylogeny of Thioploca and related filamentous sulfide-oxidizing bacteria". Systematic and Applied Microbiology 1996; 18 (4): 517-26. http://cat.inist.fr/?aModele=afficheN\&cpsi $\mathrm{dt}=2984152$.

12.- Margaret O'Leary (2008) Anaxagoras and the Origin of Panspermia Theory, Universe publishing Group, \# ISBN 978-0-595-49596-2.

13.- Varbe B, Cruveiller S, Kunst F, Lenoble P, Guillaume Meurice G G, et al. From a consortium sequence to a unified sequence: the Bacillus subtilis 168 reference genome a decade later. First Published Online: 01 June 2009,
Microbiology; 155: 1758-75, DOI: 10.1099/mic.0.027839-0.

14.- Clinton Ezell E, Newman Ezell L. Exploration of the Red Planet 1958-1978. The NASA History Series. Scientific and Technical Information Branch 1984. NASA, Washington D.C.

15.- Soffen G A. The Viking project. Journal of Geophysical Research 1977; 82 (28): 3959-70. doi:10.1029/ JS082i028p03959.

16.- Lovecraft H P. El color que cayó del cielo. Ed. Minotauro, Buenos Aires 1962.

17.- Allan Hills 84001. Meteoritical Bulletin Database. The Meteoritical Society. International Society for Meteoritics and Planetary Sciencies. https://www.lpi.usra.edu/meteor/ metbull.php? code $=604$. (Last update $6 \mathrm{dec} 2017$ ).

18.- Clinton B. Press conference held at NASA Headquarters, Washington D.C. on August 7, 1996. NASA, Mars News. com.

19.- Thomas-Keprta K, Clemett S, McKay D, Gibson E, Wentworth S. Origin of Magnetite Nanocrystals in Martian Meteorite ALH84001 Journal Geochimica et Cosmochimica Acta 2009: 73: 6631-77.

20.- Twain M. Pasando fatigas: Maravillas del Lago Mono; 38: 250-2. En: Novelas completas y ensayos. Aguilar, Madrid 1957.

21.- Wolfe Simon F, Switzer J, Kulp T R, Gordon G W et al. A bacterium that can grow by using arsenic instead of phosphorus. Science 2010; 332 (6034): 1163-6.

22.- Hayden E C. Study challenges existence of arsenic-based life. Nature 2012. doi:10.1038/nature.2012.9861.

23.- Reavers M L, Sinha S, Rabinowitz J D, Kruglyak L, Redfield R J. Absence of detectable arsenate I DNA from arsenate-grown GFAJ-1 cells. Science 2012; 337 (6093): 470-3. 